\title{
POLYPHENOLOXIDASE ACTIVITY OF MINIMALLY PROCESSED \\ 'JONAGORED' APPLES (MALUS DOMESTICA)
}

\author{
A.M.C.N. ROCHA and A.M.M.B. DE MORAIS ${ }^{1}$ \\ Escola Superior de Biotecnolgia da Universidade Católica Portuguesa \\ Rua Dr António Bernardino de Almeida \\ 4200-072 PORTO, Portugal
}

\begin{abstract}
The influence of three chemical dips using ascorbic acid (AA), citric acid $(C A)$ and calcium chloride (CC) on the polyphenoloxidase (PPO) activity and on the total phenolic content of minimally processed (MP) apple (Malus domestica, cv. Jonagored) during cold storage was evaluated and a potential relationship with enzymatic browning was investigated. An ascorbic acid dip $(42.6 \mathrm{mM})$ of $5 \mathrm{~min}$ duration was the most efficient chemical treatment in reducing the PPO activity of apple cubes. A 92\% inhibition was achieved after 7 days of storage at $4 C$. All treatments were advantageous in comparison to the control in reducing color changes. Color changes, determined by absorbance at $420 \mathrm{~nm}$ (soluble pigments) and lightness (L) (insoluble pigments) of apple cubes treated with ascorbic acid were correlated with total phenolic content. No correlation was observed between PPO activity and tristimulus color parameters, browning index or total phenolic content of AA-treated apple cubes.
\end{abstract}

\section{INTRODUCTION}

Among compounds that inhibit polyphenoloxidase (PPO) activity, sulfur dioxide $\left(\mathrm{SO}_{2}\right)$ is one of the most effective and is used in the food industry for many years (Sayavedra-Soto and Montgomery 1986; Taylor et al. 1986). However, restrictions of sulfite usage in foods associated with consumer concern about its safety generate the need for substitutes. Most of the alternatives are formulations of ascorbic acid (AA) and citric acid (CA) (Santerre et al. 1988). The quinone-reducing capacity and efficiency of AA is largely

\footnotetext{
${ }^{1}$ Corresponding author. TEL: 351-22-5580050; FAX: 351-22-5090351; EMAIL: amorais@esb.ucp.pt
} 
dependent on AA concentration. When applied at small concentrations, AA may be quickly consumed in the reducing process and may prevent the formation of colored polymers for only a limited time. Large AA concentrations may provide permanent protection against browning (Vámos-Vigyázó 1981). El-Shimi (1993) reported that treatment with $1 \%$ AA resulted in almost complete inactivation of PPO in apple slices.

AA is demonstrably less effective than $\mathrm{SO}_{2}$ in controlling browning (Sapers et al. 1989). Combinations of antibrowning agents are therefore recommended, aiming to enhance the relative activity of any single antibrowning agent individually. Because of the numerous factors that may affect the efficacy of an antibrowning agent or a combination thereof (i.e., penetration into the tissue, $\mathrm{pH}$, competing processes, side reactions), the performance of the combined agents must be evaluated empirically for each commodity (Sapers et al. 1989).

A typical combination may include a chemical reductant (e.g., AA), an acidulant (e.g., CA) and a chelating agent (ethylene diamine tetra-acetic acid or EDTA). In many cases, the enhanced activity of the combined ingredients is additive, although synergism is often claimed for experimental blends of antibrowning agents (Santerre et al. 1988).

Citric acid (CA) is often used in conjunction with AA as a chemical inhibitor of enzymatic browning (Ponting et al. 1972). Pizzocaro et al. (1993) reported that a $0.2 \%$ solution of CA resulted in little or no inhibition of PPO in 'Golden Delicious' apple cubes, and that dipping the apple cubes in a solution of $1 \%$ AA for 5 min resulted in an increase in PPO activity, while a 5 min dip in a solution containing a mixture of $1 \%$ AA and $0.2 \%$ CA resulted in $90-100 \%$ inhibition of PPO. Janovitz-Klapp et al. (1990) reported that combining 50-70 mM CA with AA exhibited little effect on the PPO activity of apples (cv. Red Delicious).

The aim of this research was to evaluate the influence of chemical solutions: $42.6 \mathrm{mM}$ AA $(0.75 \% \mathrm{w} / \mathrm{v}) ; 21.3 \mathrm{mM} \mathrm{AA}+33.8 \mathrm{mM}$ calcium chloride $(\mathrm{CC})$ and $14.2 \mathrm{mM} \mathrm{AA}+22.5 \mathrm{mM} \mathrm{CC}+13.0 \mathrm{mM} \mathrm{CA}$ on PPO activity and phenolic content of minimally processed (MP) apple cubes (cv. Jonagored) during storage at $4 \mathrm{C}$ and to observe potential relationships with enzymatic browning.

\section{MATERIALS AND METHODS}

Apples (cv. Jonagored) were grown at Estação Regional de Fruticultura e Vitivinicultura - Quinta de Sergude, Felgueiras, Portugal. The apples were harvested on September 25, 1995. Fruits were stored in air at 4C for 13 months until used in the experiments. 


\section{Treatment and Storage Conditions}

Apples stored under refrigeration were transported weekly to the laboratory in Porto. The apples for each experiment were initially washed in chlorinated water ( $150 \mathrm{ppm}$ of active chlorine for $5 \mathrm{~min}$ ) (Wardowski and Brown 1991) to prevent surface contamination. After peeling and coring, each apple was cut into cubes of approximately $1.5 \mathrm{~cm}$ and randomly selected for selected experiments. Apple cubes were dipped into a chemical solution for $5 \mathrm{~min}$, then drained in a plastic colander (Rocha et al. 1998). Control apple cubes were dipped in distilled water. The chemical solutions that were tested were: $42.6 \mathrm{mM}$ AA $(0.75 \% \mathrm{w} / \mathrm{v}) ; 21.3 \mathrm{mM} \mathrm{AA}+33.8 \mathrm{mM} \mathrm{CC}$ and $14.2 \mathrm{mM}$ $\mathrm{AA}+22.5 \mathrm{mM} \mathrm{CC}+13.0 \mathrm{mM} \mathrm{CA}$ (Rocha et al. 1998). Three replicates of 30 apple cubes were used for each experiment. The control and treated apple cubes were stored in open glass jars at $4 \mathrm{C}$ and atmospheric pressure for 7 days in the dark. The apple cubes were evaluated in terms of several quality attributes at selected times of storage.

\section{Color Assessment}

The cut apple surface color was determined with a hand-held tristimulus reflectance colorimeter (Minolta CR-300, Minolta Corp., Ramsey, NJ). The color was recorded using the CIE-L*, $a^{*}, b^{*}$ scale, where $L^{*}$ represents lightness, $\mathrm{a}^{*}$ represents chromaticity on a green $(-)$ to red $(+)$ axis and $\mathrm{b}^{*}$ represents chromaticity on a blue (-) to yellow (+) axis. Numerical values of $\mathrm{a}^{*}$ and $\mathrm{b}^{*}$ were converted into hue angle $\left(\mathrm{Hue}=\tan ^{-1}\left(\mathrm{~b}^{*} / \mathrm{a}^{*}\right)\right)$.

\section{Assay for Polyphenoloxidase (PPO) Activity}

Enzymatic activity was assayed by determining the rate of increase in absorbance at $420 \mathrm{~nm}$ and $25 \mathrm{C}$ in a Perkin-Elmer Lambda 15 UV/VIS spectrophotometer (Shimadzu Corp., Tokyo, Japan). The reaction mixture contained $3.0 \mathrm{~mL}$ of catechol substrate, the solution freshly prepared in $0.05 \mathrm{M}$ sodium phosphate buffer at $\mathrm{pH} 6.5$ and a fixed quantity of PPO. The reference cuvette contained only the catechol substrate solution. The reaction was conducted at $25 \mathrm{C}$. The linear section of the activity curve as a function of time was used to determine PPO activity (U/ $/ \mathrm{g}$ protein/min). The unit for the PPO activity was defined as a change of 0.001 in absorbance at the conditions of the assay (Galeazzi and Sgarbieri 1981; Pizzocaro et al. 1993). Determinations were performed in triplicate for each of the three replicates of each experiment.

\section{Total Phenolic Content}

Each replicate of 30 apple cubes was crushed, homogenized with water and centrifuged at $1200 \mathrm{rpm}$ for $10 \mathrm{~min}$ at $4 \mathrm{C}$. Total phenolic content was 
determined using the Folin-Ciocalteau reagent (Folin and Ciocalteau 1927; Singleton and Rossi 1965). Dopamine was used to obtain the standard curve $(0.5-5.0 \mu \mathrm{g}$ dopamine $/ \mathrm{mL})$, and the concentration of phenols was calculated directly from the standard curve because the control standards and the apple cubes were treated identically. The total phenols were expressed as $\mu \mathrm{g}$ dopamine/100 $\mathrm{g}$ of fresh weight of the apple cubes.

\section{Browning Index (BI)}

Fifty grams of frozen apples from each replicate of 10 apples were homogenized in a laboratory blender for $2 \mathrm{~min}$. Homogenates were centrifuged at $800 \mathrm{~g}$ for $25 \mathrm{~min}$ at $4 \mathrm{C}$, filtered through Whatman no. 4 filter paper (Whatman, Maidstone, Kent, UK) and the absorbance of the resulting clear juice determined immediately at $420 \mathrm{~nm}$ and reported as the Browning Index (BI). Greater absorbance at $420 \mathrm{~nm}$ corresponds to greater browning of the tissue (Wrolstad 1976).

\section{Protein Content}

Protein concentrations were determined in experimental preparations by the colorimetric method described by Bradford (1976). Protein contents were obtained by graphic interpolation on a standard curve calibrated with bovine serum albumin (BSA) at $595 \mathrm{~nm}$.

\section{Polyacrylamide Gel Electrophoresis}

The apple PPO was separated into multiple forms by a modification of the polyacrylamide gel electrophoresis (PAGE) procedure described by Davis (1964). A Bio-Rad Miniprotean II dual slab cell (Bio-Rad, Richmond, CA) was used for the electrophoresis. Bisacrylamide gels at 7.5\% were used according to Laemmli (1970), but under native conditions (i.e., without sodium dodecyl sulfate, SDS). Gels were incubated over $1 \mathrm{~h}$ in a solution of $40 \%$ methanol (v/v), $10 \%$ acetic acid (v/v) and $0.1 \%$ Coomassie Brilliant Blue R-250 (w/v) using a shaker (Heidolph, Schwabach, Germany). Gels were discolored in a solution identical to the solution described previously but without the colorant to reveal the protein bands. Gels were dried under vacuum in a Bio-Rad Gel Dryer, model 583 (Bio-Rad, Richmond, CA) during $2 \mathrm{~h}$ at $80 \mathrm{C}$, and the relative mobility (RM) was calculated.

\section{Statistical Analysis}

To compare the experiments performed on selected different dates, differences between the controls in those experiments were taken into account. 
The results from selected treatments were corrected by those differences: Corrected experimental result $2=$ experimental result $2+[$ (control $1-$ control 2 )/control (2)* experimental result 2]. Experimental result 1 was compared to corrected experimental result 2 .

SAS Institute, Inc. (1982) was used for the analysiss of the experimental data. Statistical significance was assessed by two-way analysis of variance with the source of variation resulting from chemical treatment. Significant differences $(P=0.05)$ between treatments were detected using Duncan's multiple range test. Correlation analysis was conducted between color parameters, PPO, phenolic content and BI. Attempts were made to establish the relationships between the parameters studied using " $R$ " as the correlation factor.

\section{RESULTS AND DISCUSSION}

\section{Color}

The lightness ( $\mathrm{L}^{*}$ value) of all treated apple cubes was considered advantageous in comparison to the controls in reducing color changes after 7 days of storage (Table 1$)$. The other color parameters $\left(a^{*}, b^{*}\right.$ and hue) exhibited no differences $(P>0.05)$ between the apple cubes treated with AA $+\mathrm{CC}$ and the control apple cubes (Tables 2-4). The apple cubes treated with AA exhibited the least browning, expressed as the highest $\mathrm{L}^{*}$ value (Table 1 ) and hue angle (Table 4) $(P<0.05)$ and the smallest $\mathrm{a}^{*}$ (Table 2$)$ and $\mathrm{b}^{*}$ values (Table 3$)$. After 7 days of storage, the AA dip reduced the increase of $a^{*}$ value from 49.8 to $21.7 \%$, the increase of $b^{*}$ from 26.7 to $8.7 \%$, the loss of lightness from 7.5 to $0.7 \%$ and the decrease of hue from 8.2 to $3.9 \%$. The AA + CA + CC treatment was intermediate between $\mathrm{AA}$ alone and $\mathrm{AA}+\mathrm{CC}$ in its effect on the color parameters of apple cubes during 7 days storage (Tables 1-4).

TABLE 1.

L* VALUES OF APPLE CUBES STORED AT 4C IN THE DARK*

\begin{tabular}{llll}
\hline Experimental series & \multicolumn{2}{l}{ Storage days } \\
\cline { 2 - 4 } & 0 & 3 & 7 \\
\hline Control & $80.17 \mathrm{a}^{\dagger}$ & $77.66 \mathrm{~b}$ & $74.14 \mathrm{c}$ \\
AA & $79.20 \mathrm{a}$ & $78.50 \mathrm{ab}$ & $78.65 \mathrm{a}$ \\
AA + CC & $79.57 \mathrm{a}$ & $78.13 \mathrm{~b}$ & $76.27 \mathrm{~b}$ \\
AA + CC + CA & $79.86 \mathrm{a}$ & $78.99 \mathrm{a}$ & $76.56 \mathrm{~b}$ \\
\hline
\end{tabular}

* Data are means of 3 replicates of 30 apple cubes.

Mean separation in columns by Duncan's multiple range test, $P=0.05$.

AA, ascorbic acid; CC, calcium chloride; CA, citric acid. 
TABLE 2.

a* VALUE OF APPLE CUBES STORED AT 4C IN THE DARK*

\begin{tabular}{llll}
\hline Experimental series & \multicolumn{2}{l}{ Storage days } & 7 \\
\cline { 2 - 4 } & 0 & 3 & $-3.23 \mathrm{a}$ \\
\hline Control & $-6.43 \mathrm{a}^{\dagger}$ & $-4.30 \mathrm{a}$ & $-4.99 \mathrm{c}$ \\
AA & $-6.37 \mathrm{a}$ & $-5.13 \mathrm{~b}$ & $-3.08 \mathrm{a}$ \\
AA + CC & $-6.07 \mathrm{a}$ & $-4.53 \mathrm{a}$ & $-4.33 \mathrm{~b}$ \\
AA + CC + CA & $-6.30 \mathrm{a}$ & $-5.22 \mathrm{~b}$ & \\
\hline
\end{tabular}

* Data are means of 3 replicates of 30 apple cubes.

$\dagger$ Mean separation in columns by Duncan's multiple range test, $P=0.05$.

AA, ascorbic acid; CC, calcium chloride; CA, citric acid.

TABLE 3.

b* VALUE OF APPLE CUBES STORED AT 4C IN THE DARK*

\begin{tabular}{llll}
\hline Experimental series & \multicolumn{2}{l}{ Storage days } & 7 \\
\cline { 2 - 4 } & 0 & 3 & $31.30 \mathrm{a}$ \\
\hline Control & $24.72 \mathrm{a}^{\dagger}$ & $24.22 \mathrm{a}$ & $24.80 \mathrm{c}$ \\
AA & $22.88 \mathrm{a}$ & $25.71 \mathrm{a}$ & $30.95 \mathrm{a}$ \\
AA + CC & $20.65 \mathrm{~b}$ & $22.10 \mathrm{~b}$ & $26.98 \mathrm{~b}$ \\
AA + CC + CA & $22.84 \mathrm{a}$ & $20.85 \mathrm{~b}$ & \\
\hline
\end{tabular}

* Data are means of 3 replicates of 30 apple cubes.

$\dagger$ Mean separation in columns by Duncan's multiple range test, $P=0.05$.

AA, ascorbic acid; CC, calcium chloride; CA, citric acid.

TABLE 4.

HUE OF APPLE CUBES STORED AT 4C IN THE DARK*

\begin{tabular}{llrr}
\hline Experimental series & \multicolumn{2}{l}{ Storage days } & \\
\cline { 2 - 4 } & 0 & 3 & 7 \\
\hline Control & $104.69 \mathrm{~b}^{\dagger}$ & $100.22 \mathrm{bc}$ & $96.10 \mathrm{c}$ \\
AA & $105.68 \mathrm{~b}$ & $101.43 \mathrm{~b}$ & $101.47 \mathrm{a}$ \\
AA + CC & $106.51 \mathrm{a}$ & $101.66 \mathrm{~b}$ & $95.85 \mathrm{c}$ \\
AA + CC + CA & $105.52 \mathrm{~b}$ & $104.27 \mathrm{a}$ & $99.20 \mathrm{~b}$ \\
\hline
\end{tabular}

* Data are means of 3 replicates of 30 apple cubes.

$\dagger$ Mean separation in columns by Duncan's multiple range test, $P=0.05$.

AA, ascorbic acid; CC, calcium chloride; CA, citric acid. 


\section{Polyphenoloxidase (PPO) Activity}

A lag time was observed before any change of absorbance in PPO extracts, resulting from the chemical treatments tested in comparison to control apple cubes (Table 5). Janovitz-Klapp et al. (1990), in a study with PPO extracts from Delicious apples, also reported a lag period before any change in absorbance occurred in the presence of reducing compounds such as AA.

After the 3rd day of storage, the smallest PPO activity was observed for AA-treated apple cubes. AA treatment reduced the increase of PPO activity from $\approx 40$ to $10 \%$ compared to control apple cubes after 7 days of storage. PPO extracted from AA-treated apple cubes exhibited an activity about $70 \%$ of the PPO activity of the untreated apple cubes (Table 5).

Extensive literature reports the effects of AA on PPO activity extracted from selected sources: Ponting (1954) indicated that PPO isolated from either apples or mushrooms was reversibly inactivated by AA; Janovitz-Klapp et al. (1990) reported that the enzymatic browning of apples was effectively inhibited by $0.5 \mathrm{mM} \mathrm{AA}$, and the greater the ascorbic acid concentration, the longer the lag period and the slower the rate of browning following the lag period; Pizzocaro et al. (1993) studied the effect of AA, CA and sodium chloride on PPO activity of 'Golden Delicious' apple cubes and reported that $90-100 \%$ inhibition was obtained with a $5 \mathrm{~min}$ dip in mixtures of $1.0 \%$ AA plus $0.2 \%$ CA or $1 \%$ AA plus $0.05 \% \mathrm{NaCl}$.

All of the chemical treatments in this study resulted in lower PPO activity than the control apple cubes. Nevertheless, no statistically significant differences $(P>0.05)$ were observed between apple cubes treated either with $\mathrm{AA}+\mathrm{CC}$ or $\mathrm{AA}+\mathrm{CC}+\mathrm{CA}$ after 7 days of storage (Table 5). Greater PPO activity was observed in apple cubes treated with $\mathrm{AA}+\mathrm{CC}$ or $\mathrm{AA}+\mathrm{CC}+\mathrm{CA}$

TABLE 5.

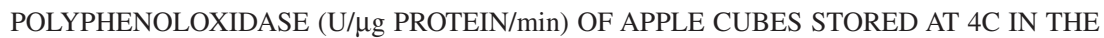
DARK*

\begin{tabular}{lllrlll}
\hline Experimental series & \multicolumn{6}{l}{ Storage days } \\
\cline { 2 - 7 } & 0 & Lag (s) & \multicolumn{1}{c}{3} & Lag (s) & 7 & Lag (s) \\
\hline Control & $11905 \mathrm{a}^{\dagger}$ & - & $15907 \mathrm{a}$ & - & $16783 \mathrm{a}$ & - \\
$\mathrm{AA}$ & $10787 \mathrm{a}$ & 6 & $9875 \mathrm{~d}$ & 6 & $11912 \mathrm{c}$ & 6 \\
$\mathrm{AA}+\mathrm{CC}$ & $11635 \mathrm{a}$ & 12 & $15260 \mathrm{~b}$ & 6 & $14656 \mathrm{~b}$ & 6 \\
$\mathrm{AA}+\mathrm{CC}+\mathrm{CA}$ & $11166 \mathrm{a}$ & 12 & $11292 \mathrm{c}$ & 12 & $14332 \mathrm{~b}$ & 6 \\
\hline
\end{tabular}

* Data are means of 3 replicates of 30 apple cubes.

Mean separation in columns by Duncan's multiple range test, $P=0.05$.

- , no lag time was observed; AA, ascorbic acid; CC, calcium chloride; CA, citric acid. 
TABLE 6.

TOTAL PHENOLS ( $\mu \mathrm{g}$ DOPAMINE/100g) OF APPLE CUBES STORED AT 4C IN THE DARK*

\begin{tabular}{llll}
\hline Experimental series & \multicolumn{2}{l}{ Storage days } & \\
\cline { 2 - 4 } & 0 & 3 & 7 \\
\hline Control & $1221.8 \mathrm{c}^{\dagger}$ & $1397.4 \mathrm{c}$ & $1243.4 \mathrm{c}$ \\
$\mathrm{AA}$ & $2279.9 \mathrm{~b}$ & $4226.2 \mathrm{a}$ & $4224.8 \mathrm{a}$ \\
$\mathrm{AA}+\mathrm{CC}$ & $3919.7 \mathrm{a}$ & $2804.6 \mathrm{~b}$ & $2464.5 \mathrm{~b}$ \\
$\mathrm{AA}+\mathrm{CC}+\mathrm{CA}$ & $3213.9 \mathrm{a}$ & $2908.4 \mathrm{~b}$ & $2891.3 \mathrm{~b}$ \\
\hline
\end{tabular}

* Data are mean of 3 replicates of 30 apple cubes.

$\dagger$ Mean separation in columns by Duncan's multiple range test, $P=0.05$.

AA, ascorbic acid; CC, calcium chloride; CA, citric acid.

when compared to apple cubes treated only with AA, attributable to the greater water loss observed for the $\mathrm{AA}+\mathrm{CC}$ or $\mathrm{AA}+\mathrm{CC}+\mathrm{CA}$ treatments which may have resulted to membrane damage and to a release of PPO or substrate (Nunes et al. 1995).

\section{Total Phenolic Content}

The chemical treatments selected resulted in an increase $(P<0.05)$ in the phenolic content of the apple cubes for both storage times (Table 6). AAtreated apple cubes exhibited the greatest phenolic content $(P<0.05)$ after the 3rd day of storage. AA resulted in a stabilizing effect on the metabolism of the phenols as reported by Lattanzio and Linsalata (1989). No differences $(P>0.05)$ were observed between the apple cubes treated with AA $+\mathrm{CC}$ or $\mathrm{AA}+\mathrm{CC}+\mathrm{CA}($ Table 6$)$.

\section{Browning Index (BI)}

AA-treated apple cubes exhibited the lowest BI after the 3rd day of storage, confirming the results of the color difference experiments (Tables 14). The lowest BI corresponds to the least browning of the apple tissues (Wrolstad 1976). After 7 days of storage, no differences were detected between the control apple cubes and the apple cubes treated with $\mathrm{AA}+\mathrm{CC}$ or AA $+\mathrm{CC}+\mathrm{CA}(P>0.05)($ Table 7$)$.

\section{Electrophoretic Data}

Chemical treatments did not affect the electrophoretic pattern of PPO extracted from the Jonagored apples stored for 7 days of at 4C. Only one band 
TABLE 7.

BROWNING INDEX $\left(\mathrm{A}_{420}\right)$ OF APPLE CUBES STORED AT 4C IN THE DARK*

\begin{tabular}{llll}
\hline Experimental series & \multicolumn{2}{l}{ Storage days } & 7 \\
\cline { 2 - 4 } & 0 & 3 & $0.22 \mathrm{a}$ \\
\hline Control & $0.09 \mathrm{~b}^{\dagger}$ & $0.18 \mathrm{a}$ & $0.12 \mathrm{~b}$ \\
$\mathrm{AA}$ & $0.10 \mathrm{~b}$ & $0.12 \mathrm{~b}$ & $0.18 \mathrm{a}$ \\
$\mathrm{AA}+\mathrm{CC}$ & $0.13 \mathrm{a}$ & $0.16 \mathrm{a}$ & $0.19 \mathrm{a}$ \\
$\mathrm{AA}+\mathrm{CC}+\mathrm{CA}$ & $0.14 \mathrm{a}$ & $0.15 \mathrm{a}$ & \\
\hline
\end{tabular}

* Data are means of 3 replicates of 30 apple cubes.

$\lceil$ Mean separation in columns by Duncan's multiple range test, $P=0.05$.

AA, ascorbic acid; CC, calcium chloride; CA, citric acid.

TABLE 8.

CORRELATION $\left(R^{2}\right)$ BETWEEN SEVERAL PARAMETERS OF APPLE CUBES AFTER STORAGE

\begin{tabular}{lllll}
\hline & $\begin{array}{l}\text { Quality } \\
\text { parameters }\end{array}$ & Phenolic content & PPO activity & BI \\
\hline Color & L* value & 0.96 & - & 0.96 \\
& a* value $^{*}$ & 0.99 & 0.02 & 0.99 \\
& b* value & 0.90 & 0.06 & 0.90 \\
& Hue & 0.99 & - & 0.99 \\
Browning index & Chroma & 0.86 & - & 0.86 \\
PPO activity & & 0.99 & $\mathrm{x}$ & $\mathrm{x}$ \\
\hline
\end{tabular}

- , no correlation was observed.

$R^{2}$ at a level $P=0.05$.

was detected with an RM of 0.45 towards the anode, agreeing with a previous study (Rocha and Morais 2001a).

\section{Relationship Between Color, BI, Total Phenolic Content and PPO Activity}

Attempts were made to establish the relationships among the parameters studied for AA-treated apple cubes, because AA treatment was the best treatment for the preservation of the quality of fresh apple cubes. Large correlations were obtained between color parameters and the total phenolic contents or the BI of apple cubes (Table 8). A negative correlation observed between 
$\mathrm{L}^{*}$ value and $\mathrm{BI}$ demonstrated that the greater the degree of browning encountered, the smaller the lightness ( $\mathrm{L}^{*}$ value) of the apple cubes as previously observed for untreated apple cubes (Rocha and Morais 2001b).

A linear correlation was obtained when the total phenolic content was plotted against the browning index (Table 8), suggesting that the BI may be determined by the concentration of phenolic substrates present in the apples (Harel et al. 1966).

No correlations were observed when PPO activity was plotted against color parameters, BI, or total phenolic content (Table 8) of AA-treated apple cubes. Color changes in apple cubes treated with AA, determined by absorbance at $420 \mathrm{~nm}$ (soluble pigments), expressed as the BI and lightness (insoluble pigments) expressed as $\mathrm{L}^{*}$ value, were correlated with the total phenolic content. The total phenols in apple cubes are closely related to the color changes that occur in apple cubes during storage (Table 8).

\section{ACKNOWLEDGMENT}

This research was funded by a JNICT scholarship (BD 2109/92-IF).

\section{REFERENCES}

BRADFORD, M.M. 1976. A rapid and sensitive method for the quantitation of microgram quantities of protein utilizing the principle of protein binding. Anal. Biochem. 72, 248-254.

DAVIS, B.J. 1964. Disk electrophoresis. 2. Method and application to human serum proteins. Ann. N Y Acad. Sci. 121, 404-410.

EL-SHIMI, N. 1993. Control of enzymatic browning in apple slices by using ascorbic acid under different conditions. Plant Foods Hum. Nutr. 43, 7176.

FOLIN, D. and CIOCALTEAU, V. 1927. On tyrosine and tryptophane determinations in proteins. J. Biol. Chem. 12, 239-241.

GALEAZZI, M.A.M. and SGARBIERI, V.C.J. 1981. Substrate specificity and inhibition of polyphenoloxidase from a dwarf variety of banana (Musa cavendishii L.). J. Food Sci. 46, 1404-1406.

HAREL, E., MAYER, A.M. and SHAIN, Y. 1966. Catechol oxidases, endogenous substrates and browning in developing apples. J. Sci. Food Agric. 17, 389-392.

JANOVITZ-KLAPP, A.H., RICHARD, F.C., GOUPY, P.M. and NICOLAS, J.J. 1990. Inhibition studies on apple polyphenol oxidase. J. Agric. Food Chem. 38, 926-931. 
LAEMMLI, U.K. 1970. Cleavage of structural proteins during assembly of the head of bacteriophage T4. Nature 227, 680.

LATTANZIO, V. and LINSALATA, V. 1989. The beneficial effect of citric acid and ascorbic acid on the phenolic browning reaction in stored artichoke (Cynara scolymus L.) Heads. Food Chem. 33, 93-106.

NUNES, M.C.N., MORAIS, A.M.M.B., BRECHT, J.K. and SARGENT, S.A. 1995. Quality of strawberries after storage in controlled atmospheres at above optimum storage temperatures. Proc. Fla. State Hortic. Soc. 108, 273.

PIZZOCARO, F., TORREGGIANI, D. and GILARDI, G. 1993. Inhibition of apple polyphenoloxidase by ascorbic acid, citric acid and sodium chloride. J. Food Process. Pres. 17, 21-30.

PONTING, J.D. 1954. Reversible inactivation of polyphenol oxidase. J. Am. Chem. Soc. 76, 662-664.

PONTING, J.D., JACKSON, R. and WATTERS, G. 1972. Refrigerated apple slices: Preservative effects of ascorbic acid, calcium and sulfites. J. Food Sci. 37, 434-437.

ROCHA, A.M.C.N., BROCHADO, C.M. and MORAIS, A.M.M.B. 1998. Influence of chemical treatment on quality of minimally processed apple (cv. Jonagored). J. Food Quality 21, 13-28.

ROCHA, A.M.C.N. and MORAIS, A.M.M.B. 2001a. Characterization of polyphenoloxidase (PPO) extracted from "Jonagored" apple. Food Control 12, 85-90.

ROCHA, A.M.C.N. and MORAIS, A.M.M.B. 2001b. Polyphenoloxidase activity and total phenolic content as related to browning of minimally processed 'Jonagored' apple. J. Sci. Food Agric. 82, 120-126.

SANTERRE, C.R., CASH, J.N. and VANNORMAN, D.J. 1988. Ascorbic acid/citric acid combinations in the processing of frozen apple slices. J. Food Sci. 53, 1713-1716.

SAPERS, G.M., DOUGLAS, F.W., BILYK, A., HSU, A.F., DOWER, H.W., GARZARELLA, L. and KOZEMPEL, M. 1989. Enzymatic browning in Atlantic potatoes and related cultivars. J. Food Sci. 54, 362-365.

SAS Institute, Inc. SAS. 1982. User's guide: Statistics. Cary, N.C.

SAYAVEDRA-SOTO, L.A. and MONTGOMERY, M.W. 1986. Inhibition of polyphenoloxidase by sulfite. J. Food Sci. 51, 1531-1536.

SINGLETON, V.L. and ROSSI, J.A. Jr 1965. Colorimetry of total phenolics with phosphomolybdic - phosphotungstic acid reagents. Am. J. Enol. Vitivinic. 16, 144-158.

TAYLOR, S.L., HUGLEY, N.A. and BUSH, R.K. 1986. Sulfites as food ingredients. Food Technol. 40, 47-52.

VÁMOS-VIGYÁZÓ, L. 1981. Polyphenol oxidase and peroxidase in fruits and vegetables. Crit. Rev. Food Sci. Nutr. 9, 49-127. 
WARDOWSKI, W.F. and BROWN, G.E. 1991. Postharvest Decay Control Recommendations for Florida Citrus Fruit. Circular 952. Institute of Food and Agricultural Sciences, University of Florida, Gainesville, FL.

WROLSTAD, R.E. 1976. Color and Pigment Analyses in Fruit Products. Station Bulletin No. 624. Agricultural Experiment Station, Oregon State University, Corvallis, OR. 